\title{
Interactive comment on "Mesospheric
} temperature soundings with the new, daylight-capable IAP RMR lidar" by M. Gerding et al.

M. Gerding et al.

gerding@iap-kborn.de

Received and published: 15 July 2016

The comment was uploaded in the form of a supplement:

http://www.atmos-meas-tech-discuss.net/amt-2016-135/amt-2016-135-AC2-

supplement.pdf

Interactive comment on Atmos. Meas. Tech. Discuss., doi:10.5194/amt-2016-135, 2016. 